于露, 王红梅, 郭天斗, 杨青莲, 孙忠超.荒漠草原-灌丛镶嵌体的植被稳态转变特征.生态学报,2021,41(24):9773-9783.

Yu L, Wang H M, Guo T D, Yang Q L, Sun Z C. Bistable-state of vegetation shift in the desert grassland-shrubland anthropogenic Mosaic area. Acta Ecologica Sinica,2021,41(24):9773-9783.

\title{
荒漠草原-灌丛镶嵌体的植被稳态转变特征
}

\author{
于 $\quad$ 露 $^{1}$, 王红梅 $^{1,2}{ }^{*}$, 郭天斗 ${ }^{3}$, 杨青莲 ${ }^{1}$, 孙忠超 $^{1}$ \\ 1. 宁夏大学农学院, 银川 750021 \\ 2. 西北退化生态系统恢复与重建教育部重点实验室, 银川 750021 \\ 3. 甘肃亚盛农业研究院有限公司, 兰州 730070
}

摘要: 以柠条锦鸡儿( Caragana korshinskii) 灌丛引人形成荒漠草原-灌丛地镶嵌体为研究对象,选择其内部荒漠草地 (DG)、草地 边缘 $(\mathrm{GE})$ 、灌丛边缘 $(\mathrm{SE})$ 、灌丛地 $(\mathrm{SL})$ 为试验样地, 开展荒漠草原向灌丛地人为稳态转变过程土壤水分与植被变化特征研究。 结果如下: 各样地 0-200 cm 土层水分含量随着转变过程呈显著降低趋势 $(P<0.05)$, 其中荒漠草地、草地边缘和灌丛边缘样地 的土壤水分均在秋季雨水补充期增加,灌丛地由于深层土壤水分过度消耗而愈加降低,且灌丛边缘和灌丛地深层水分显著低于 荒漠草地、草地边缘 $(P<0.05)$, 垂直动态不显著; 地上植被随样地转变除优势度指数表现为灌丛地多样性、均匀度、丰富度指数 均显著低于各样地 $(P<0.05)$, 多年生优势草本蒙古冰草 (Agropyron mongolicum)、短花针茅 ( Stipa breviflora) 逐渐被一年生草本 刺慦 (Dysphania aristata)、猪毛蒿( Artemisia scoparia) 所代替; 土壤种子库萌发种类随样地转变逐渐减少, 种子库密度则显著升 高 $(P<0.05)$, 灌丛地以一年生草本植物为主 (占总密度的 $97.51 \%)$, 荒漠草地则以多年生草本萌发为主, 且各样地土壤萌发种 子库及多年生草本多集中于 $0-5 \mathrm{~cm}$ 土层 $(P<0.05)$; 转变过程荒漠草原和灌丛地植被地上地下相似度分别为 0.14 和 0.19 , 均 显著低于两边缘样地 0.35 , 较两边缘样地群落更为稳定, 呈现草原灌丛化过程中草地-灌丛共存的植被双稳态特征。

关键词:草原灌丛化; 稳态转变; 土壤水分;地上植被;土壤种子库

\section{Bistable-state of vegetation shift in the desert grassland-shrubland anthropogenic Mosaic area}

\author{
YU Lu ${ }^{1}$, WANG Hongmei ${ }^{1,2, *}$, GUO Tiandou ${ }^{3}$, YANG Qinglian ${ }^{1}$, SUN Zhongchao ${ }^{1}$ \\ 1 College of Agriculture, Ningxia University, Yinchuan 750021, China \\ 2 Ministry of Education Key Laboratory for Restoration and Reconstruction of Degraded Ecosystem in Northwest China, Yinchuan 750021, China \\ 3 Gansu Yasheng Agricultural Research Institute Co.Ltd, Lanzhou 730070, China
}

\begin{abstract}
In this paper, desert grassland, grassland edge, shrub edge, and shrubland were selected as four transition sites in a typical anthropogenic desert grassland-shrubland mosaic in desert steppe of eastern Ningxia, China. The soil moisture, above-vegetation and soil seed bank were investigated to understand the response of vegetation to the desert grasslandshrubland state anthropogenic transition. The results showed that the soil moisture of $0-200 \mathrm{~cm}$ soil layer in each site presented a significant downward trend with the transition $(P<0.05)$, and the soil moisture in desert grassland, grassland edge and shrubland edge were increased with the autumn rain supplement, while that in shrubland decreased due to the depletion of the deep soil water by shrubs. The deep soil moisture in shrubland edge and shrubland were significantly lower than those in desert grassland, grassland edge $(P<0.05)$, while there were in no significant vertical distribution dynamics
\end{abstract}

基金项目:国家自然科学基金项目(31860677); 国家重点研发计划课题(2016YFC0500505); 宁夏科技支撑计划项目( 2015 惠民计划); 宁夏高等 学校一流学科建设资助项目 (NXYLXK2017A01)

收稿日期: 2020-01-20; 网络出版日期:2021-08-04

* 通讯作者 Corresponding author.E-mail: whm_826@163.com 
in these two sites. Except for the dominance index, the diversity, uniformity, and richness indexes in the shrubland were significantly lower than those in other three sites $(P<0.05)$, and the perennial dominant herbs Agropyron mongolicum, Stipa breviflora were gradually replaced by annual herbs Dysphania aristata and Artemisia scoparia. The germination species number of soil seed bank decreased gradually, however, the density of seed banks increased significantly with the transition $(P<0.05)$, and the soil seed banks germinated in shrubland were dominated by annual herbs (accounting for $97.51 \%$ of the total density), while which in desert grassland were mainly perennial herb. And the germination of soil seed bank and perennial herb in four sites were concentrated in $0-5 \mathrm{~cm}$ soil layer $(P<0.05)$; The similarity coefficient $(\mathrm{SC})$ between above-ground vegetation and underground soil bank in the grassland and shrubland were 0.14 and 0.19 , respectively, which were significantly lower than the SC in the two edge sites $(0.35)$, and the two sites were relatively stable than the edge sites, occurring the bistable state of vegetation shift in the process of desert grassland-shrubland anthropogenic transition.

Key Words : shrub encroachment ; regime shift ; soil moisture; aboveground plant; soil seed bank

草原灌丛化是一种发生在全球性范围的干旱、半干旱生态系统内灌木植物生物量及密度有所上升的现 象 ${ }^{[1]}$, 在草地向灌丛地长期转变过程中 $\mathrm{C}_{3}$ 木本植物竞争优势优于 $\mathrm{C}_{4}$ 草本植物, 造成禾本科多年生草本大量减 少、草本植物受到较大干扰并最终使得灌丛间裸地形成 ${ }^{[1-3]}$ 。草原灌丛化一旦开始, 它们对多年生禾草的扩 张和更替就不再受人为活动的限制, 从而进行大面积扩散并维持长期状态, 造成不可逆性变化 ${ }^{[4]}$ 。

稳态转变是指生态系统结构和功能的持续变化, 而这些改变显著影响生态系统服务功能,危及生物多样 性, 扰乱人类生计 ${ }^{[4-5]}$, 通常情况下稳态转变是由于内部和外部驱动因素的渐变或骤变所驱动 ${ }^{[6]}$, 因此相关学 者致力于研究制定通用方法和指标来避免和应对生态系统稳态转变的影响, 其中干旱半干旱地区草原向灌丛 地转变被公认为是生态系统稳态转变的典型实例 ${ }^{[4]}$ 。因其脆弱性和广泛性, 对于干旱到半干旱的草原和稀 树草原在稳态转变的研究占据突出地位。多年生草原和稀树草原可以经历持续、广泛的向灌丛或林地的过 渡, 以草本植物覆盖度的大量骤减为主要特点 ${ }^{[4]}$ 。目前全球范围内草地向灌丛转变的原因、影响及可逆性有 所差异, 但一致认为全球气候变化、放牧、火烧减少、人为干扰等因素超过草地所能承受临界阈值时, 演替将草 地从多年生草本覆盖率高的稳定状态向以灌木或一年生草本与灌丛共存的稳定状态推动, 最后进人灌丛稳态 阶段。但驱动稳态转变因素的阈值水平可能不同于将系统转换回来所需的阈值,因此这种滞后效应很难使灌 丛逆转回初始草地状态 ${ }^{[6]}$, 尤其是在大尺度下反馈所驱动的转变过程 ${ }^{[4,7]}$, 因此全球范围内的草原灌丛化是 全球气候变化下生态系统稳态转变的表现。而这一转变过程主要以土壤性质、植被构成、种子库、营养再生潜 力的差异为特征 ${ }^{[7-10]}$ 。在演替中植被与种子库变化最为明显, 且两者具有如下联系: 过渡前期土壤种子库与 地上植被之间相似性较高, 后期两者逐渐出现显著差异, 并且在演替前期或干扰性较高的区域, 地上植被与土 壤种子库之间相似性普遍较高 ${ }^{[11]}$ 。在全球气候变化影响下, 宁夏东部荒漠草原自人为引人大量灌丛用于植 被重建以来, 逐渐出现深层土壤水分过度消耗、水土空间异质性增加 ${ }^{[12]}$, 以及生态干旱及植被多样性丧 失 ${ }^{[13]}$ 。同时人工灌丛引人也导致了该地区出现大面积的草地-灌丛镶嵌体, 呈现出不同程度草地和灌丛植物 群落的相对稳定特征。近年来大量研究集中在自然人侵下的灌丛化现象 ${ }^{[2,3,14-15]}$, 以及灌丛人侵后的植被和 土壤变化 ${ }^{[7-8,16-17]}$,但对于人为灌丛引人导致的稳态转变研究极少。

基于宁夏东部荒漠草原灌丛长时间和大面积引人现状, 选取典型草地-灌丛镶嵌体, 利用野外调查和室内 模拟培养方法, 开展荒漠草地向灌丛地人为转变过程中的植被、地境演变及土壤种子库特征研究, 以期了解荒 漠草地-灌丛地人为稳态转变过程中植被群落动态和响应特征, 为荒漠草原植被重建的恢复和可持续性提供 理论和数据支持。 


\section{1 试验方法和材料}

\section{1 研究区概况}

研究区(图 1) 位于宁夏盐池县花马池镇四墩子村, 其地理位置为 $\left(37^{\circ} 04^{\prime}-38^{\circ} 10^{\prime} \mathrm{N}, 106^{\circ} 03^{\prime}-107^{\circ} 04^{\prime} \mathrm{E}\right)$, 海拔为 $1380 \mathrm{~m}$ 左右, 属于典型温带大陆性气候, 年平均 气温 $7.7^{\circ} \mathrm{C}$, 年平无霜期有 $162 \mathrm{~d}$ 左右。年平均降水量 $250-350 \mathrm{~mm}$, 全年降水量的 60\%-70\% 所发生在 7-9 月份,年蒸发量 $2131.8 \mathrm{~mm}$ 。本研究区草地类型为荒漠 草原, 以灰钙土为主要土壤类型, 土壤结构松散, 土壤 贫痊。

\section{2 试验地概况}

本试验以宁夏盐池县宁夏大学草业科学实验基地 为基础,选取具有典型代表性的荒漠草原区 (DG)、草地 边缘 (GE)、灌丛边缘 $(\mathrm{SE}) 、$ 柠条锦鸡儿灌丛区 $(\mathrm{SL})$ 为

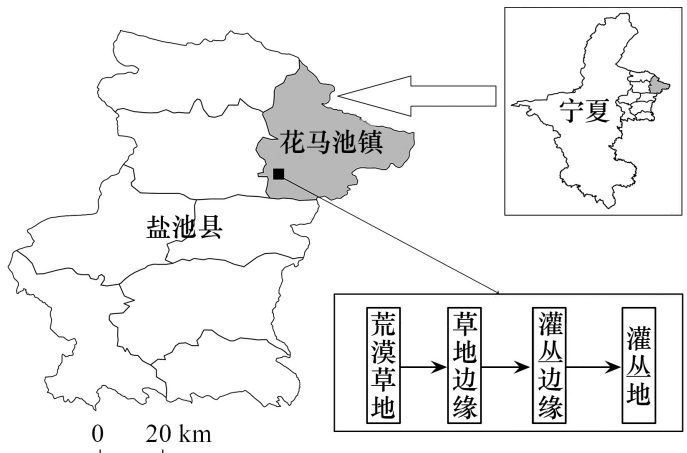

图 1 研究区及试验采样点分布图

Fig.1 The location and the distribution of sampling sites 4 个研究样地 (图 1, 表 1), 分别在草原及草地边缘随机各设置 6 个 $5 \mathrm{~m} \times 5 \mathrm{~m}$ 样区, 灌丛(间距 $6 \mathrm{~m}$, 种植年限 30 年) 及灌丛边缘分别跨越带间、带内各设置 3 个 $10 \mathrm{~m} \times 10 \mathrm{~m}$ 样区为本试验固定监测样区。

\section{表 1 样地概况}

Table 1 Sites description

\begin{tabular}{|c|c|c|c|c|c|c|}
\hline $\begin{array}{l}\text { 样地 } \\
\text { Site }\end{array}$ & $\begin{array}{l}\text { 代号 } \\
\text { Code }\end{array}$ & $\begin{array}{l}\text { 经纬度 } \\
\text { Latitude and } \\
\text { longitude }\end{array}$ & $\mathrm{pH}$ & $\begin{array}{l}\text { 有机碳 } \\
\text { Organic } \\
\text { carbon/ } \\
(\mathrm{g} / \mathrm{kg})\end{array}$ & $\begin{array}{l}\text { 全氮 } \\
\text { Total } \\
\text { nitrogen/ } \\
(\mathrm{g} / \mathrm{kg})\end{array}$ & $\begin{array}{l}\text { 优势植物 } \\
\text { Dominant species }\end{array}$ \\
\hline $\begin{array}{l}\text { 荒漠草地 } \\
\text { Desert grassland }\end{array}$ & DG & $\begin{array}{l}107^{\circ} 16^{\prime} 24^{\prime \prime} \mathrm{E} \\
37^{\circ} 46^{\prime} 31^{\prime \prime} \mathrm{N}\end{array}$ & 8.35 & 8.37 & 0.36 & $\begin{array}{l}\text { 蒙古冰草 (Agropyron mongolicum), 短花针茅 } \\
\text { (Stipa breviflora), 猪毛蒿 (Artemisia scoparia) 等 }\end{array}$ \\
\hline $\begin{array}{l}\text { 草地边缘 } \\
\text { Grassland edge }\end{array}$ & GE & $\begin{array}{l}107^{\circ} 16^{\prime} 08^{\prime \prime} \mathrm{E} \\
37^{\circ} 46^{\prime} 32^{\prime \prime} \mathrm{N}\end{array}$ & 8.19 & 8.14 & 0.31 & $\begin{array}{l}\text { 牛枝子 (Lespedeza potaninii), 草木䨄状黄花 } \\
\text { (Astragalus melilotoides), 乳浆大戟 (Euphorbia } \\
\text { esula) 等 }\end{array}$ \\
\hline $\begin{array}{l}\text { 灌丛边缘 } \\
\text { Shrubland edge }\end{array}$ & $\mathrm{SE}$ & $\begin{array}{l}107^{\circ} 17^{\prime} 43^{\prime \prime} \mathrm{E} \\
37^{\circ} 43^{\prime} 59^{\prime \prime} \mathrm{N}\end{array}$ & 8.34 & 5.17 & 0.29 & $\begin{array}{l}\text { 柠条锦鸡儿 ( Caragana Korshinskii), 短花针茅, } \\
\text { 远志 (Polygala tenuifolia) 等 }\end{array}$ \\
\hline $\begin{array}{l}\text { 灌丛地 } \\
\text { Shrubland }\end{array}$ & SL & $\begin{array}{l}107^{\circ} 17^{\prime} 52^{\prime \prime} \mathrm{E} \\
37^{\circ} 44^{\prime} 55^{\prime \prime} \mathrm{N}\end{array}$ & 8.39 & 3.93 & 0.39 & $\begin{array}{l}\text { 柠条锦鸡儿, 猪毛蒿, 刺藜 (Dysphania } \\
\text { aristata) 等 }\end{array}$ \\
\hline
\end{tabular}

\section{3 研究方法}

\subsection{1 土壤水分测定}

分别在上述 4 个样地内 (各 6 个样区) 的样区内进行定点观测。采用时域反射仪 (Time Domain Reflectometry, TDR) 对土壤水分进行观测, 每个样区设置 2 个重复, 每个样地共计 12 个重复, 测定时通过不同 方向 (4 次) 调整 TDR 管读取数据并及时记录,每月 $1-2$ 次, 观测深度为 $0-200 \mathrm{~cm}$,每 $20 \mathrm{~cm}$ 为一层,共 10 层, 观测时间为 2019 年 4-11 月。

\subsection{2 野外植被调查}

于 2019 年 7 月下旬一 8 月下旬各样地的每个样区内外随机设置 3 个面积为 $1 \mathrm{~m} \times 1 \mathrm{~m}$ 的草本样方,各样 地植被调查样方数 18 个, 共计 72 个草本样方总数。采样时需注意要避开样地边缘 $30 \mathrm{~m}$ 减少误差, 以调查草 本物种盖度、高度、密度、频度及地上生物量。采用收获法测定地上生物量, 然后齐地面刚割所有物种, 称其鲜 重, 带回实验室 $65^{\circ} \mathrm{C}$ 烘干至恒重, 计算样区植被地上生物量 (灌木地生物量确定通过单位面积上的灌丛数目, 选取 3-5 株灌丛取其八分之一生物量,并与草本单位面积生物量相加获得)。 


\subsection{3 土壤种子库取样与萌发}

采用直接萌发法来检测土壤种子库的物种构成及其数目,该实验开始于 2019 年 3 月初 ( 因经过冬季低温 过程), 分别在荒漠草原、草地边缘、灌丛边缘和灌丛地上设置固定观测样区点 (6个), 利用 $10 \mathrm{~cm} \times 10 \mathrm{~cm}$ 取样 器在每个采样区内随机选取植丛和空斑作为 2 个重复样点进行分层 $(0-5 \mathrm{~cm}, 5-10 \mathrm{~cm})$ 取土采样。将取回 样品进行后续土壤种子库萌发工作。土壤风干后除去原样品中较大的砾石和粗根系, 过 $0.25 \mathrm{~mm}$ 土壤篮进行 种子篮选之后将土样均匀铺设在内径 $15 \mathrm{~cm}$ 、高 $15 \mathrm{~cm}$ 塑料花盆( 塑料花盆底部预先填充 $5 \mathrm{~cm}$ 厚、无种子的蛭 石) 中。因考虑到部分植物在 $3 \mathrm{~cm}$ 以下土层中难以破土萌发, 所以铺设在蛭石上的土样厚度应控制在 $3 \mathrm{~cm}$ 以内, 最后在适宜温度环境 (光照长度为 $12 \mathrm{~h}$, 温度 $20-25^{\circ} \mathrm{C}$ ) 下进行萌发试验。根据前期研究土壤水分得出 研究区田间持水量为 $21.26 \% \pm 1.89 \%$, 将 $22 \%$ 作为基准含水量进行适时、底部浇水来保持土壤湿度。自幼苗 开始萌发进行定期观察, 用标签进行标记以记录萌发情况, 在此期间添加 $40 \mathrm{mg} / \mathrm{L}$ 营养液/月 ( $5 \mathrm{~mL}$ 营养液:

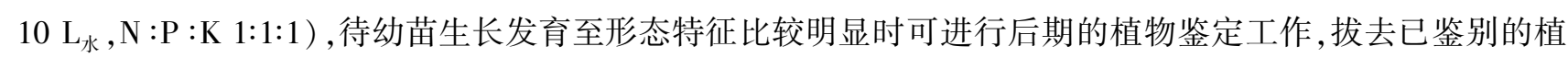
株。连续观测 5 周后若无种子萌发, 则认为土样中种子已完全萌发。

\section{4 数据分析}

采用 SPSS 软件中的单因素方差分析 (one-way ANOVA) 对不同样地土壤种子库物种萌发总密度进行统计 分析, 用最小显著差异法 (LSD) 检验进行多重比较检验, 显著水平为 0.05 。根据各群落物种土壤种子库密度 与地上植被盖度分别进行物种种子库与地上植被相关分析, 均值为各样地内空斑和植丛土壤种子库密度根据 植从和空斑盖度加权后平均所得。同时采用 Excel 2010、Origin Pro 8 软件进行作图。

(1) 土壤种子库密度统计: 将 $10 \mathrm{~cm} \times 10 \mathrm{~cm}$ 取样面积内种子萌发数量换算为 $1 \mathrm{~m} \times 1 \mathrm{~m}$ 的种子数目, 即种 子库密度采用单位面积内所含有的种子数量来表示;

(2) 采用以下公式进行物种多样性指数计算 ${ }^{[9]}$ :

(1)Sorensen 相似性 ( similarity coefficient, $S C$ ) :

$$
S C=\frac{2 w}{a+b}
$$

式中, $w$ 为土壤种子库和地上植被共有的植物种数; $a$ 和 $b$ 分别为土壤种子库和地上植被的植物种数;

(2)Shannon-wiener 指数:

$$
D=-\sum P_{i} \ln P_{i}
$$

式中 $P=\frac{N_{i}}{N} ; N$ 为群落中个体总数量 (或总生物量); $N_{i}$ 为种 $i$ 的数量 (或生物量)。

(3)Margalef 丰富度指数 $(M a)$ :

$$
M a=\frac{S-1}{\ln N}
$$

式中: $S$ 为群落中物种总数; $N$ 为观察到的物种数目 (随样方大小而增减)。

(4)Pielou 均匀度指数 $(H)$ :

$$
H=\frac{D}{\ln S}
$$

式中: $D$ 为多样性指数; $S$ 为群落中物种的数量。

\section{2 结果与分析}

2.1 荒漠草原向灌丛地人为转变过程土壤水分特征

2.1.1 土壤水分季节动态特征

荒漠草原向灌丛地人为转变中土壤水分季节动态变化如图 2 所示: 各样地平均水分含量依次为荒漠草地 


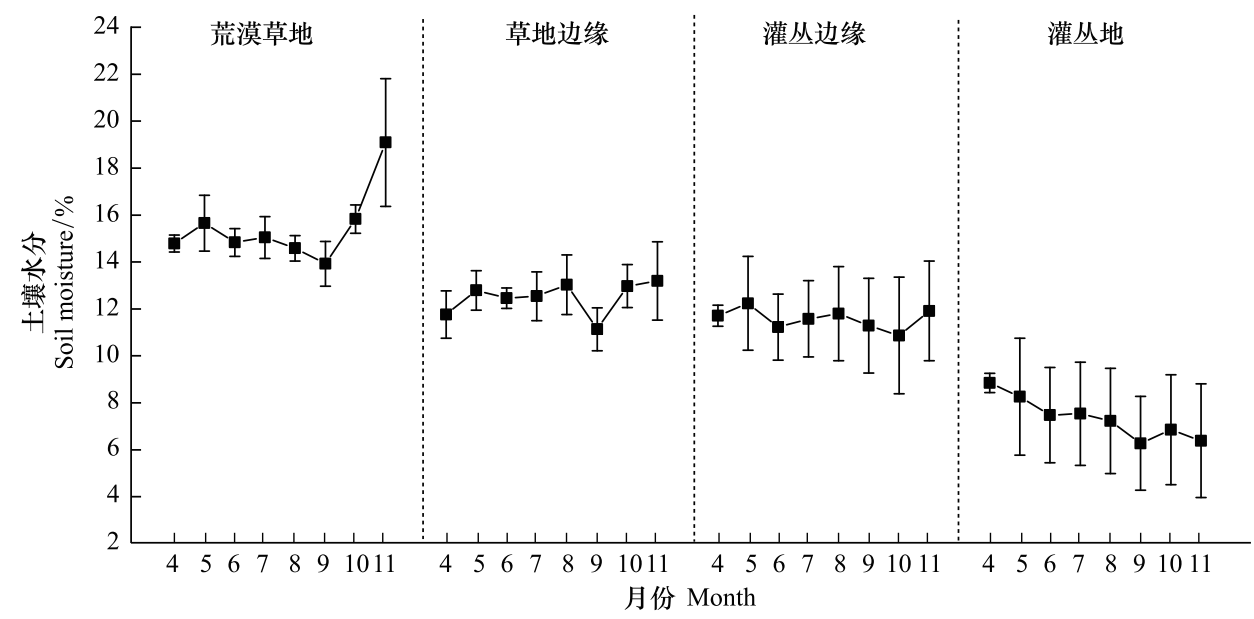

图 2 荒漠草原向灌丛地人为转变下土壤水分季节变化

Fig.2 Seasonal dynamics of soil moisture with the desert grassland- shrubland anthropogenic transition

$(15.47 \%)>$ 草地边缘 $(12.48 \%)>$ 灌丛边缘 $(11.58 \%)>$ 灌丛地 $(7.36 \%)$, 荒漠草原和灌丛地间土壤水分差距最 大为 $8.11 \%$, 各转变样地土壤水分均随着生长季呈下降趋势, 但经过了雨水补充期, 荒漠草地土壤水分在秋季 迅速得以补偿, 高达 $15.83 \%$,两边缘样地秋季土壤水分补充不显著, 而灌丛地则呈降低趋势, 低至 $6.28 \%$ 。

\subsection{2 土壤水分垂直变化特征}

在荒漠草原逐渐向灌丛地人为转变过程土壤水分垂 直变化特征如图 3 所示: 各样地 0-100 $\mathrm{cm}$ 土壤水分 (5.38\%-14.01\%) 显著低于深层 120-200 cm ( 8.97\%$17.38 \%)$; 土壤水分含量分布深度均有所不同: 荒漠草地 在 $200 \mathrm{~cm}$ 处最高, $40 \mathrm{~cm}$ 最低, 分别为 $22.24 \%$ 和 $11.15 \%$; 草地边缘则分别在 $180 \mathrm{~cm} 、 60 \mathrm{~cm}$ 达到最值,分 别为 $7.56 \%$ 和 $15.09 \%$; 灌丛边缘和灌丛地均在 $60 \mathrm{~cm}$ 处达到水分最低值,分别为 $8.53 \% 、 3.83 \%$; 但两者水分 最大值所处土层深度不同，依次为 $160 \mathrm{~cm}(13.96 \%)$ 和 $200 \mathrm{~cm}(10.88 \%)$ 。

2.2 荒漠草原向灌丛地人为转变过程的植物群落特征

2.2.1 地上植被变化特征

野外植被调查数据表明荒漠草原向灌丛地人为转 变过程中物种数量有所减少, 由荒漠草原的 24 种递减

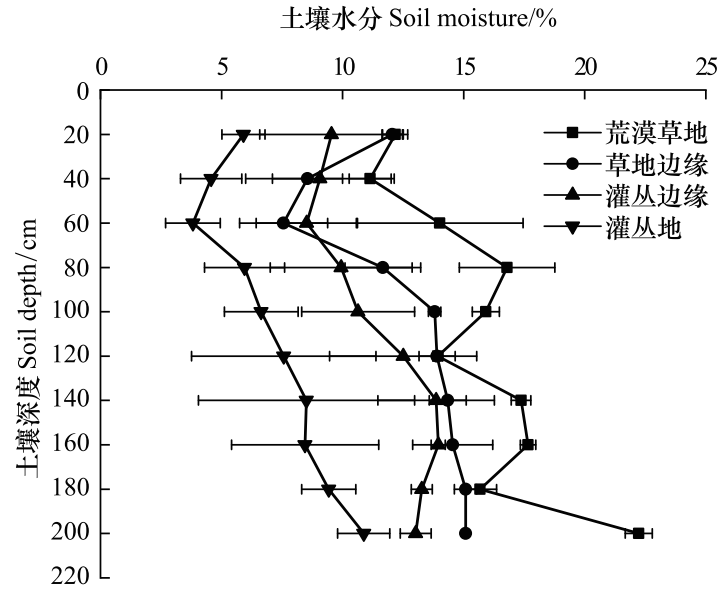

图 3 荒漠草原向灌丛地人为转变下土壤水分垂直分布特征

Fig.3 Vertical distribution of soil moisture with the desert grassland- shrubland anthropogenic transition

至灌丛地的 16 种。多年生草本由最初 15 种减至 7 种;一年生草本种类增多。荒漠草原主要以多年生草本为 主, 占总物种数 $62.5 \%$, 一年生草本占 $25 \%$; 各生活型间差异显著 $(P<0.05)$; 而灌丛边缘内一年生与多年生草 本虽物种数相同,但总体数量以一年生草本最多;草地边缘和灌丛边缘均以多年生草本为主。

由图 4 所示, 荒漠草地-灌丛地人为转变过程中各样地密度之间存在显著差异 $(P<0.05)$, 其中荒漠草地密 度最大为 197.00 株 $/ \mathrm{m}^{2}$, 灌丛地最小为 19.79 株 $/ \mathrm{m}^{2}$; 草本盖度由最初荒漠草原的 $70 \%$ 降至灌丛地的 $12.65 \%$; 灌木盖度增至 $49.96 \%$,且各样地间差异明显 $(P<0.05)$ 。

通过调查发现: 草本地上生物量以草地边缘最多, 为 $0.19 \mathrm{~kg} / \mathrm{m}^{2}$, 以荒漠草地最低为 $0.06 \mathrm{~kg} / \mathrm{m}^{2}$, 各样地内显 著差异 $(P<0.05)$; 灌丛地上生物量随灌丛不断扩张呈递增趋势, 最终以灌丛地最高为 $2.22 \mathrm{~kg} / \mathrm{m}^{2}$, 各样地间灌丛 生物量差异明显 $(P<0.05)$ 。地上总生物量差值最大的样地为荒漠草地和灌丛地,两者间相差 $2.28 \mathrm{~kg} / \mathrm{m}^{2}$ 。 
表 2 荒漠草地-灌丛地人为转变过程中地上植被组成变化

Table 2 Species composition with the desert grassland- shrubland anthropogenic transition

\begin{tabular}{ccccc}
\hline 代号 & $\begin{array}{c}\text { 物种数目 } \\
\text { Species number }\end{array}$ & $\begin{array}{c}\text { 多年生草本 } \\
\text { Perennial herb }\end{array}$ & $\begin{array}{c}\text { 一年生草本 } \\
\text { Annual herb }\end{array}$ & $\begin{array}{c}\text { 半灌木 } \\
\text { Semi-shrub }\end{array}$ \\
\hline DG & 24 & 15 & 6 & 3 \\
GE & 19 & 12 & 3 & 4 \\
SE & 16 & 9 & 5 & 2 \\
SL & 16 & 7 & 7 & 2 \\
\hline
\end{tabular}
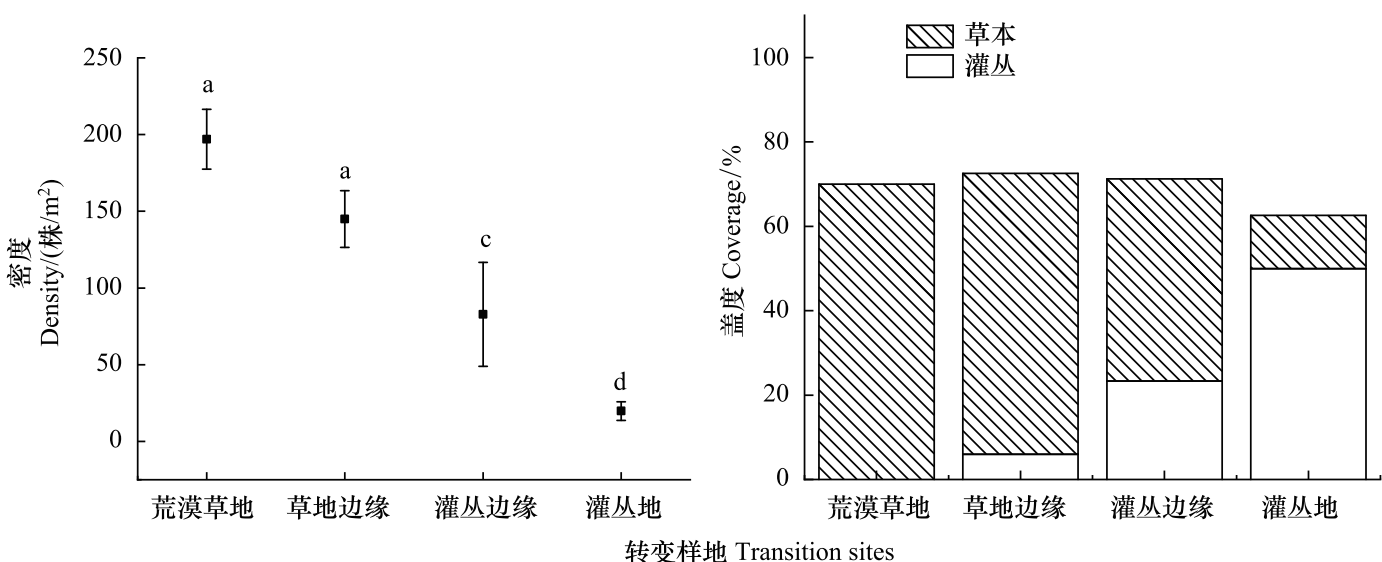

转变样地 Transition sites

图 4 荒漠草原向灌丛地人为转变过程地上植被密度和盖度变化

Fig.4 Density and coverage with the desert grassland- shrubland anthropogenic transition 不同字母表示不同样地内植被密度的差异显著 $(P<0.05)$

表 3 荒漠草地向灌丛地人为转变过程下生物量变化

Table 3 The biomass with the desert grassland- shrubland anthropogenic transition

\begin{tabular}{cccc}
\hline $\begin{array}{c}\text { 样地 } \\
\text { Plot }\end{array}$ & $\begin{array}{c}\text { 灌木生物量 } \\
\text { The coverage of shrub } /\left(\mathrm{kg} / \mathrm{m}^{2}\right)\end{array}$ & $\begin{array}{c}\text { 草本生物量 } \\
\text { The coverage of herbs } /\left(\mathrm{kg} / \mathrm{m}^{2}\right)\end{array}$ & $\begin{array}{c}\text { 总生物量 } \\
\text { The biomass of vegetation } /\left(\mathrm{kg} / \mathrm{m}^{2}\right)\end{array}$ \\
\hline DG & $0.00 \pm 0.00 \mathrm{c}$ & $0.06 \pm 0.00 \mathrm{c}$ & $0.06 \pm 0.00 \mathrm{c}$ \\
$\mathrm{GE}$ & $0.02 \pm 0.00 \mathrm{c}$ & $0.19 \pm 0.00 \mathrm{a}$ & $0.21 \pm 0.01 \mathrm{bc}$ \\
$\mathrm{SE}$ & $0.30 \pm 0.19 \mathrm{~b}$ & $0.13 \pm 0.01 \mathrm{~b}$ & $0.43 \pm 0.17 \mathrm{bc}$ \\
$\mathrm{SL}$ & $2.22 \pm 0.16 \mathrm{a}$ & $0.12 \pm 0.05 \mathrm{~b}$ & $2.34 \pm 0.25 \mathrm{a}$ \\
\hline
\end{tabular}

不同字母表示不同样地内植被生物量的差异显著 $(P<0.05)$

\subsection{2 地上植被物种多样性特征}

随着荒漠草原向灌丛地人为转变过程各样地物种多样性有所变化 (图 5): Margalef 丰富度指数总体呈递 减趋势, 由荒漠草地的 2.87 减少至灌丛地的 1.81 ; Pielou 均匀度、Shannon-wiener 多样性均随着灌丛引人过程 呈先上升后下降的趋势, 两者均以草地边缘最高, 此时为 $0.87 、 2.29$, 分别减至 $0.54 、 1.24$ 。而 Simpson 优势度 则与前者相反, 随灌丛密度升高而呈上升趋势, 最终在灌丛地达到最大值 0.45 ; Margalef 丰富度指数在各样地 内均有显著差异 $(P<0.05)$ 。

3.3 荒漠草原向灌丛地人为转变过程土壤种子库变化特征

\subsection{1 土壤种子库植被构成}

通过室内萌发法处理各样地土壤种子库,最终鉴定出植物种类 16 种, 隶属于 7 科 15 属。各样地内萌发 种类数量依次为灌丛边缘 $(11$ 种 $)>$ 草地边缘 $(9$ 种 $)>$ 荒漠草地 $(7$ 种 $)>$ 灌丛地 $(6$ 种 $)$ 。土壤种子库密度随草 地-灌丛地人为转变过程逐渐增加, 以灌丛地最高为 1930 粒 $/ \mathrm{m}^{2}$, 样地间存在明显差异 $(P<0.05)$; 萌发植物所 属生活型亦有所差异, 荒漠草原样地内主要以禾本科多年生草本为主, 灌丛地则以一年生草本植物为主。 

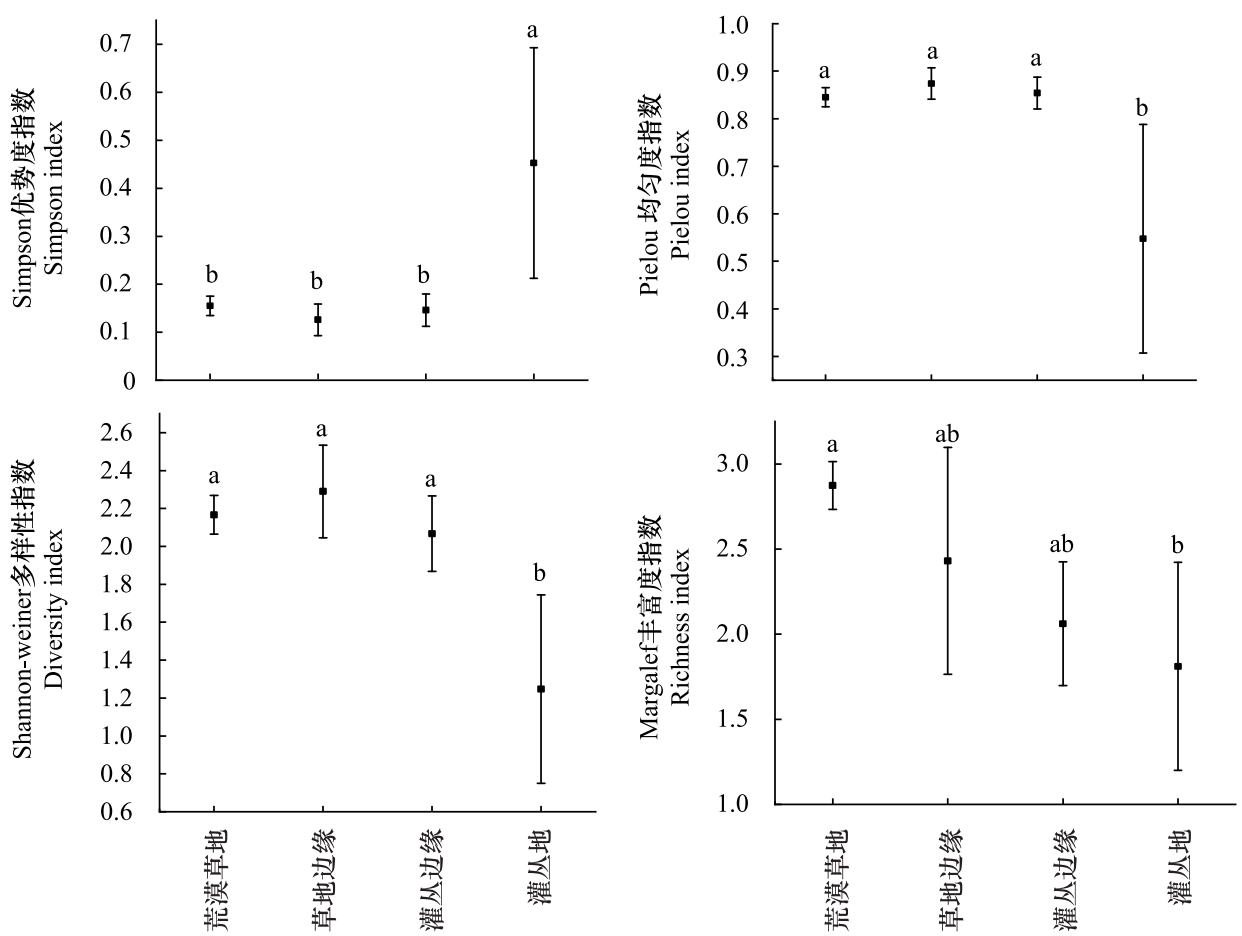

转变样地 Transition sites

图 5 荒漠草地向灌丛地人为转变地上植被物种多样性特征

Fig.5 Species diversity of aboveground vegetation with the desert grassland-shrubland anthropogenic transition 不同字母表示物种多样性差异显著 $(P<0.05)$

表 4 荒漠草地向灌丛地人为转变土壤种子库物种组成及密度

Table 4 Species composition and density of soil seed bank with the desert grassland-shrubland anthropogenic transition

\begin{tabular}{|c|c|c|c|c|c|c|}
\hline \multirow{2}{*}{$\begin{array}{l}\text { 生活型 } \\
\text { Life forms }\end{array}$} & \multirow{2}{*}{$\begin{array}{l}\text { 科 } \\
\text { Family }\end{array}$} & \multirow{2}{*}{$\begin{array}{l}\text { 种 } \\
\text { Species }\end{array}$} & \multicolumn{4}{|c|}{$\begin{array}{l}\left.\text { 土壤种子库密度/(粒/ } \mathrm{m}^{2}\right) \\
\text { The density of soil seed bank }\end{array}$} \\
\hline & & & DG & GE & $\mathrm{SE}$ & $\mathrm{SL}$ \\
\hline 一年生草本 & 禾本科 Gramineae & 狗尾草 Subsp viridis & 50 & 0 & 11 & 0 \\
\hline \multirow[t]{6}{*}{ Annual herbs } & 藜科 Chenopodiaceae & 刺藜 D. aristata & 150 & 410 & 255 & 716 \\
\hline & 菊科 Compositae & 猪毛蒿 A. scoparia & 0 & 311 & 399 & 766 \\
\hline & 酢浆草科 Oxalidaceae & 酢浆草 Oxalis corniculata & 0 & 22 & 11 & 0 \\
\hline & 藜科 Chenopodiaceae & 猪毛菜 Salsola collina & 0 & 0 & 100 & 400 \\
\hline & 禾本科 Poaceae & 画眉草 Eragrostis pilosa & 0 & 0 & 22 & 0 \\
\hline & & 总计 Total number & 200 & 743 & 798 & 1882 \\
\hline 多年生草本 & 禾本科 Poaceae & 蒙古冰草 A. mongolicum & 183 & 166 & 22 & 16 \\
\hline \multirow[t]{7}{*}{ Perennial herbs } & 禾本科 Gramineae & 白草 Pennisetum flaccidum & 67 & 110 & 55 & 0 \\
\hline & 禾本科 Gramineae & 短花针茅 S. breviflora & 117 & 0 & 0 & 0 \\
\hline & 禾本科 Gramineae & 鋉隐子草 Cleistogenes squarrosa & 100 & 0 & 0 & 0 \\
\hline & 菊科 Compositae & 丝叶山苦荬 Ixeris chinensis & 0 & 0 & 22 & 0 \\
\hline & 大戟科 Euphorbiaceae & 乳浆大戟 E. esula & 0 & 0 & 155 & 0 \\
\hline & 禾本科 Gramineae & 赖草 Leymus secalinus & 0 & 66 & 0 & 16 \\
\hline & & 总计 Total number & 467 & 342 & 254 & 32 \\
\hline \multirow[t]{5}{*}{ 灌木 Shrub } & 萝藦科 Asclepiadaceae & 老瓜头 Cynanchum komarovii & 83 & 0 & 22 & 0 \\
\hline & 菊科 Compositae & 黑沙蒿 Artemisia ordosica & 0 & 0 & 0 & 16 \\
\hline & 豆科 Leguminosae & 柠条锦鸡儿 Caragana korshinskii & 0 & 16 & 0 & 0 \\
\hline & & 植物种类 Species number & 7 & 9 & 11 & 6 \\
\hline & & 总计 Total number & $750 \mathrm{c}$ & $1101 b$ & $1074 b$ & $1930 \mathrm{a}$ \\
\hline
\end{tabular}




\subsection{2 土壤种子库变化特征}

由图 6 可知,各样地土壤种子库多集中于 $0-5 \mathrm{~cm}$ 土层中, 各样地在此土层中种子库密度依次为灌丛地 $\left(1200\right.$ 粒 $\left./ \mathrm{m}^{2}\right)>$ 草地边缘 (711 粒/ $\left.\mathrm{m}^{2}\right)$ > 灌丛边缘 (699 粒 $\left./ \mathrm{m}^{2}\right)>$ 荒漠草地 ( 500 粒 $\left./ \mathrm{m}^{2}\right)$, 分别占各自样地种子 库密度的 $66.66 \% 、 64.63 \% 、 65.08 \% 、 62.17 \%$, 且差异显 著 $(P<0.05)$; 荒漠草地和草地边缘内萌发出来的多年 生草本密度最多,而随着转变不断发生, 灌丛边缘、灌丛 地所萌发出来的物种逐渐以一年生草本为主。

图 7 所示不同微环境中土壤种子库主要贮存于植 丛下, 以灌丛地植被下土壤种子库密度最多, 为 2266 粒 $/ \mathrm{m}^{2}$, 占总密度的 $53.96 \%$; 以荒漠草地最少, 为 1133 粒 $/ \mathrm{m}^{2}$, 占该样地的 $73.96 \%$; 各样地间植被与空斑存在 显著差异 $(P<0.05)$ 。同一样地内不同微环境下种子库 生活型分布有所不同: 荒漠草地和草地边缘内植丛和空 斑均以萌发多年生草本为主; 而灌丛边缘和灌丛地则以 一年生草本为主。

\subsection{3 土壤种子库物种多样性特征}

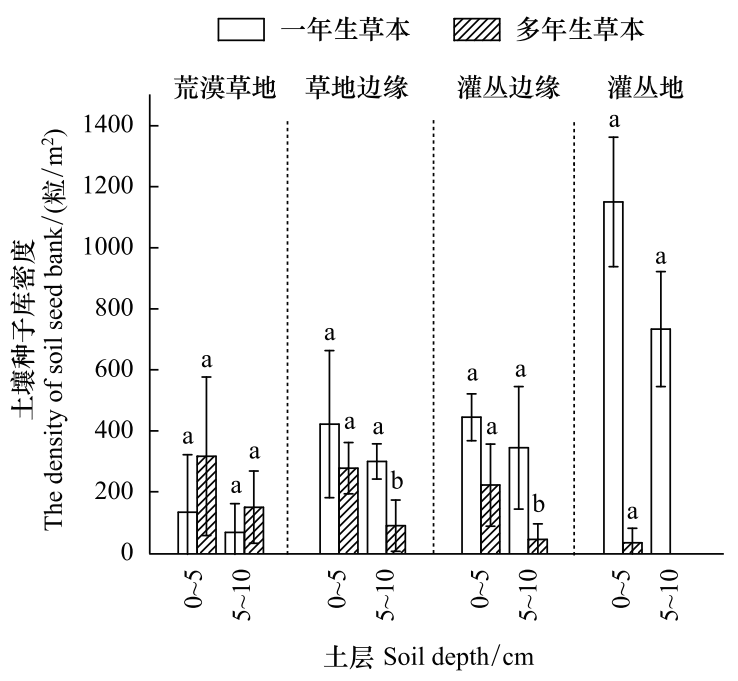

图 6 荒漠草地向灌丛地人为转变下土壤种子库密度变化

Fig. 6 Densities of soil seed bank with the desert grasslandshrubland anthropogenic transition

不同字母表示土壤种子库密度差异显著 $(P<0.05)$

各样地内土壤种子库物种多样性特征如下 (表 7)： Shannon-wiener 多样性指数、Pielou 均匀度指数均以草地边缘最高, 分别为 $1.41 、 0.64 、 0.35$, 与最低值之间分别 相差 $0.76 、 0.28 、 0.16$; Margalef 丰富度指数则以灌丛边缘最高, 为 1.42 , 相差最小值 0.99 , 各样地大小依次为灌 丛边缘 $>$ 草地边缘 $>$ 荒漠草地 $>$ 灌丛地。灌丛地内各指标均低于各样地, 其中以 Margalef 丰富度差值最大, 为 0.99 , 以上 3 个指标均呈先升高后减低趋势, 并存在显著差异 $(P<0.05)$ 。
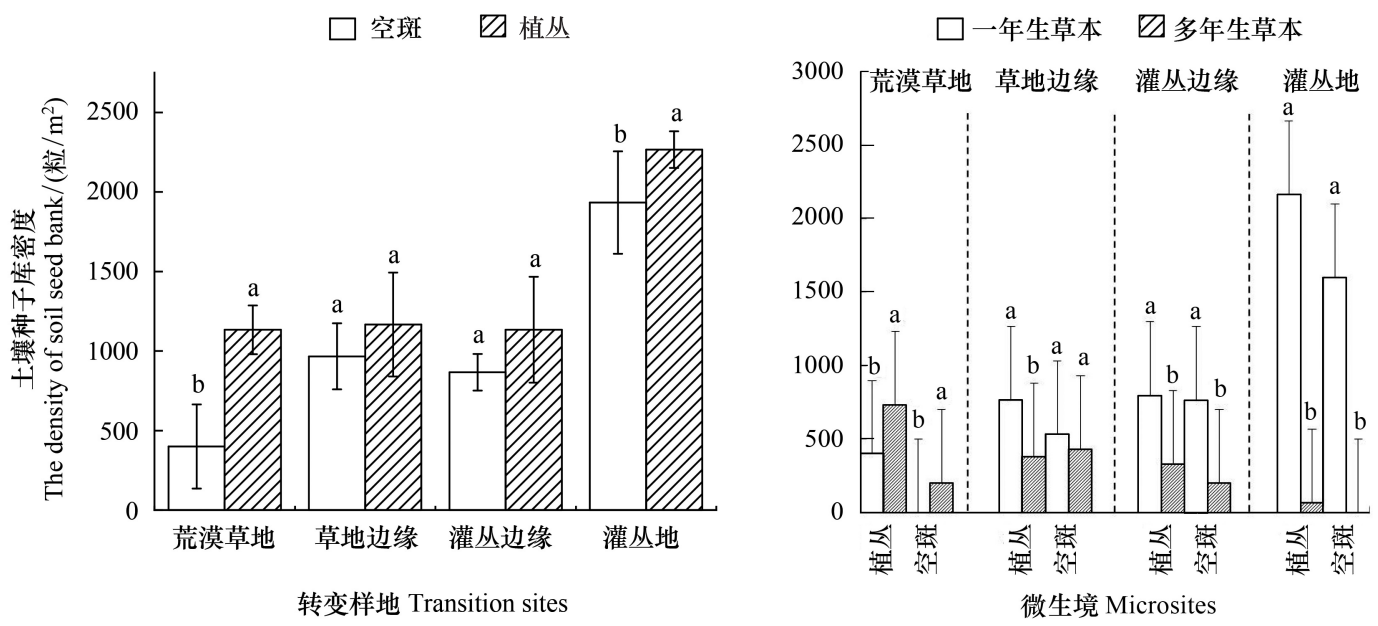

图 7 荒漠草地向灌丛地人为转变下微环境下土壤种子库分布

Fig.7 Distribution of soil seed bank in microsites with the desert grassland- shrubland anthropogenic transition

\subsection{4 地上地下植被相似性变化特征}

由图 8 可知土壤种子库与地上植被相似性为 $0.14-0.35$, 表现为两边缘样地显著高于荒漠草地和灌丛地 $(P<0.05)$, 其中两边缘样地均为 0.35 , 荒漠草地和灌丛地分别为 $0.14 、 0.19$, 随人为转变过程呈现出先升高后 降低趋势。 
表 5 荒漠草地向灌丛地人为转变下土壤种子库物种多样性特征

Table 5 Species diversity of soil seed bank with the desert grassland- shrubland anthropogenic transition

\begin{tabular}{cccc}
\hline $\begin{array}{c}\text { 样地 } \\
\text { Plot }\end{array}$ & $\begin{array}{c}\text { Shannon-wiener 多样性 } \\
\text { Shannon-wiener diversity }\end{array}$ & $\begin{array}{c}\text { Pielou 均匀度 } \\
\text { Pielou uniformity }\end{array}$ & $\begin{array}{c}\text { Margalef 丰富度 } \\
\text { Margalef richness }\end{array}$ \\
\hline DG & $0.73 \pm 0.75 \mathrm{~b}$ & $0.37 \pm 0.38 \mathrm{~b}$ & $0.62 \pm 0.54 \mathrm{ab}$ \\
GE & $1.41 \pm 0.37 \mathrm{a}$ & $0.64 \pm 0.17 \mathrm{a}$ & $0.80 \pm 0.57 \mathrm{ab}$ \\
SE & $1.10 \pm 0.44 \mathrm{a}$ & $0.46 \pm 0.18 \mathrm{~b}$ & $1.42 \pm 0.03 \mathrm{a}$ \\
SL & $0.65 \pm 0.63 \mathrm{~b}$ & $0.36 \pm 0.35 \mathrm{c}$ & $0.43 \pm 0.37 \mathrm{~b}$ \\
\hline
\end{tabular}

不同字母表示土壤种子库物种多样性差异显著 $(P<0.05)$

\section{3 讨论}

3.1 荒漠草原向灌丛地人为转变过程土壤水分响应 草原灌丛化作为全球所面临的严峻生态问题之一， 通过改变草地生态系统结构及功能,进而影响其生态水 文等过程 ${ }^{[1]}$ 。水分是干旱半干旱区域的主要限制因 素, 驱动着土壤-植被-大气连续体内这一营养物质流动 循环,对植被体吸收利用土壤养分有直接作用,间接地 影响了植被群落结构组成及其生理功能 ${ }^{[18]}$ 。本研究结 果中随着人为灌丛转变过程,土壤水分递减,与罗梦娇 等 ${ }^{[19]}$ 研究相近, 这与草本植物根系浅、盖度相对较大、 植物枯落物层厚等特点阻滞了土壤水分蒸发,且提升了 部分土壤的人渗和保水能力有关, 而且灌木植物主根系 较深且侧根极为发达, 能够充分吸收深层以及浅层 $(0-30 \mathrm{~cm})$ 土壤水分,使得草本盖度降低,裸露地面积 增加,加速灌丛地土壤水分蒸发迅速 ${ }^{[1,12]}$ 。本研究土壤

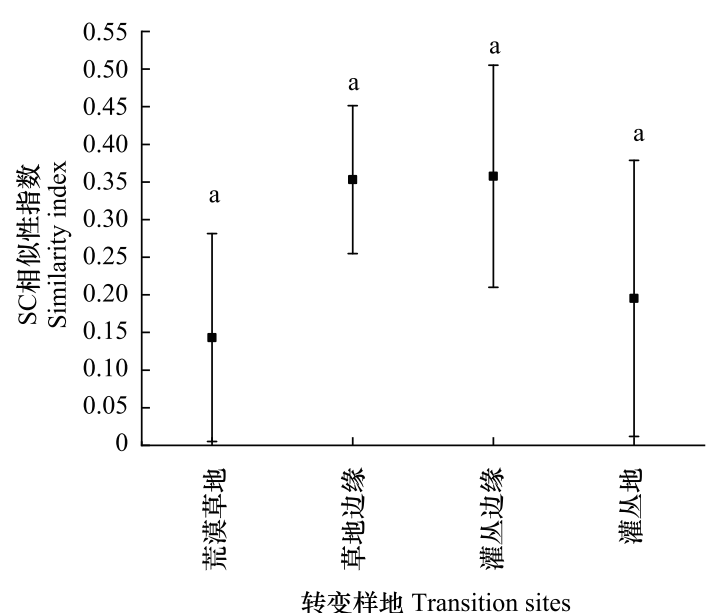

图 8 荒漠草地向灌丛地人为转变下地上地下植被相似度变化 Fig. 8 Similarity coefficient of aboveground and underground vegetation with the desert grassland-shrubland anthropogenic transition 水分季节特征表现为春季返潮上升期-夏季生长消耗 期-秋季补充增长期,这说明季节变化下土壤水分与所处环境中季节变化表现虽有推迟但大致同步 ${ }^{[20]}$,与宋 乃平等 ${ }^{[21]}$ 研究结果相符合。在气候和植被共同作用下,灌丛地土壤深层水分消耗量大造成春季返潮不明显, 土壤含水量低,但灌丛生长需水较强,除地表蒸发失水外,地上植被维持自身所需水分以及植物蒸腾作用等大 量消耗土壤水分 ${ }^{[20]}$,使得降水集中期的雨水优先补充更深层次的耗水 ${ }^{[22]}$, 因此 $0-200 \mathrm{~cm}$ 土层土壤水分无 明显补充上升。各样地内土壤表层 0-100 $\mathrm{cm}$ 水分变化幅度较大,深层土壤水分波动较小,其根本在于土壤 表层影响因素较多,如地表风速、降水、太阳辐射、植被盖度等; 且灌木根系在长期延伸过程中会与周围土壤进 行相互作用, 从而在土壤中形成相对互通的大孔隙, 改变了土壤渗透和水力传导特性 ${ }^{[18,22]}$, 使得灌丛地在 $20-60 \mathrm{~cm}$ 土壤水分波动最大。

3.2 荒漠草原向灌丛地人为转变过程草本植物群落与土壤种子库响应

草原灌丛化与生态系统结构和功能之间联系紧密,随着灌木不断人侵扩张, 影响着草地生态系统内物种 多样性和结构组成 ${ }^{[1,2,23]}$ 。植被调查发现随着荒漠草地向灌丛地人为转变, 物种种类减少、灌木盖度明显增 加; 同时草本地上生物量也有所上升, 主要以一年生草本为主, 这与班嘉蔚等 ${ }^{[24]}$ 、图雅等 ${ }^{[25] 、 Z a v a l e t a ~}$ 和 Kettley 等 ${ }^{[26]}$ 研究结果相近。总结其原因主要有以下几点: (1) 相较于禾本科植物, 木本植物的寿命和营养再 生能力较强, 能够到达草本植物无法到达的土壤深度, 且灌木能够在更长的时间内保持光合活性以及极强的 遮荫能力, 导致相互竞争作用下的多年生草本多样性骤减 ${ }^{[27]} ;(2)$ 灌木定植率高于死亡率, 除大量争夺土壤养 分外, 还降低了本地植物的丰富度, 特别是减少了禾本科的数量, 使得生物量显著下降, 并显著增加了裸露区 
域面积,最终使得物种结构简单化 ${ }^{[2,4,8]}$, 同时草原灌丛化形成的 “沃岛效应” 有利于土壤有效养分的积累,进 一步促进灌木植物生长并增加其生物量。多尺度因素共同驱动构成不同覆盖程度下荒漠草地-灌丛地镶嵌 体 ${ }^{[4]}$, 本文中“草地边缘” 和“灌丛边缘”, 作为生态界面理论中的“过渡带”、“交错带”, 这一界面中生态特征 梯度与相邻斑块之间差异显著 ${ }^{[28-29]}$, 本研究中各样地物种多样性以草地边缘、灌丛边缘最高、植物种类较丰 富这一结果与彭海英 ${ }^{[30]}$ 等人结论相近, 说明草地边缘、灌丛边缘与周边环境物质交换较为频繁 ${ }^{[31]}$ 。

土壤种子库作为植被更新过程中的主要来源, 不仅调控着植被演替方向及速率, 也参与着植被自然演替 和恢复 ${ }^{[32]}$ 。本研究人为转变过程中土壤种子库变化范围为 750-1930 粒 $/ \mathrm{m}^{2}$, 灌丛地土壤种子库密度显著高 于其他 3 个样地, 多以一年生种子为主, 且多集中在植丛下, 这可能是草原灌丛化导致土壤水分与地上植被的 差异 ${ }^{[33-35]}$, 以及在灌丛引人和扩张进程中由于植株高度等因素减缓了植被附近的风速, 利于种子大量堆积, 从而造成了土壤种子库密度及其分布差异。结果中各样地内 $62.17 \%-66.66 \%$ 种子总密度存在于 $0-5 \mathrm{~cm}$ 土 层, 这一结论与前人研究相近 ${ }^{[36]}$, 这主要由种子物理特征 (如形状、大小等) 、土壤结构及动物活动等因素所 决定, 大种子难以进人土壤深层, 而小种子可顺利进人土壤深处, 所以不同深度土层包含有特定形态的种子, 种子所处的土壤位置不但影响后期萌发定植活动, 而且也会影响植物群落结构组成 ${ }^{[37]}$ 。本实验结果中地上 植被与土壤种子库之间的相似性具体表现为荒漠草地-草地边缘转变过程中地上地下相似度有所升高, 这代 表转变进入初期阶段; 在两边缘样地间差距不大, 具备较高的地上与地下植被相似性, 说明转变演替过程中的 不稳定阶段; 灌丛边缘一灌丛地过程中相似度下降, 则说明转变过程进入后期 ${ }^{[4,38]}$, 这符合 Okin 等和 $\mathrm{D}^{\prime}$ Odorico 等的灌草竞争模型, 即荒漠草地和灌丛地较两边缘样地更为稳定, 向灌丛地稳态转变过程中出现了两 生态系统稳定共存的现象, 且这种转变难以逆转 ${ }^{[2,7]}$, 主要是两边缘样地内草本植物与灌木的激烈竞争导致 生态系统内土壤水分受到限制的同时,对于环境影响更为敏感; 而荒漠草地和灌丛地能够充分利用资源, 能维 持群落结构稳定 ${ }^{[30-31]}$ 。因此在灌丛引人过程中会出现荒漠草原生态系统和灌丛生态系统共存的植被群落双 稳态特征。

\section{参考文献 (References) :}

[ 1 ] 蔡文涛, 来利明, 李贺神, 周继华, 管天玉, 张晓龙, 高楠楠, 郑元润. 草地灌丛化研究进展. 应用与环境生物学报, 2016, 22(4)： 531-537.

[ 2 ] D'Odorico P, Okin G S, Bestelmeyer B T. A synthetic review of feedbacks and drivers of shrub encroachment in arid grasslands. Ecohydrology. $2012,5(5): 520-530$.

[ 3 ] Archer S R, Andersen E M, Predick K I, Schwinning S, Steidl R J, Woods S R. Woody plant encroachment: causes and consequences// Briske D D, ed. Rangeland Systems: Processes, Management and Challenges. Springer. 2017.

[ 4 ] Bestelmeyer B T, Peters D P C, Archer S R, Browning D M, Okin G S, Schooley R L, Webb N P. The grassland-shrubland regime shift in the southwestern united states: misconceptions and their implications for management. BioScience, 2018, 68(9): 678-690.

[ 5 ] Rocha J C, Peterson G D, Biggs R. Regime shifts in the anthropocene: drivers, risks, and resilience. Plos one, 2015, 10( 8) : e0134639.

[ 6 ] Luvuno L, Biggs R, Stevens N, Esler K. Woody Encroachment as a Social-Ecological Regime Shift. Sustainability, 2018, $10(7)$ : 2221.

[ 7 ] Okin G S, D'Odorico P, Archer S R. Impact of feedbacks on Chihuahuan desert grasslands: Transience and metastability. Journal of geophysical research: Biogeosciences, 2009, 114( G1): G01004.

[ 8 ] Guido A, Salengue E, Dresseno A. Effect of shrub encroachment on vegetation communities in Brazilian forest-grassland mosaics. Perspectives in Ecology and Conservation, 2017, 15(1):52-55.

［9］包秀霞, 廉勇, 易津, 包秀平. 不同放牧方式下克氏针茅草原退化等级的评价. 中国草地学报, 2015, 37(6): 62-66.

[10] 曾彦军, 王彦荣, 南志标, 卫东, 陈善科 李保尔. 阿拉善干旱荒漠区不同植被类型土壤种子库研究. 应用生态学报, 2003, 14(9)： 1457-1463.

[11] 尚占环, 徐鹏彬, 任国华, 龙瑞军. 土壤种子库研究综述一一植被系统中的作用及功能. 草业学报, 2009, 18(2): 175-183.

[12] 赵亚楠, 于露, 周玉蓉, 王红梅, 马千虎, 陆琪. 宁夏东部荒漠草原灌从引人对土壤水分动态及亏缺的影响. 生态学报, 2020, 40(4)： 1305-1315.

[13] Harrison S P, Gornish E S, Copeland S. Climate-driven diversity loss in a grass-land community. Proceedings of the National Academy of Sciences of the United States of America, 2015, 112(28): 8672-8677. 
[14] van Auken O W.Shrub invasions of North American semiarid grasslands. Annual Review of Ecology and Systematics, $2000,31: 197-215$.

[15] Li P X, Wang N, He W M, Krüsi B O, Gao S Q, Zhang S M, Yu F H, Dong M. Fertile islands under Artemisia ordosica in inland dunes of northern China: effects of habitats and plant developmental stages. Journal of Arid Environments, 2008, $72(6)$ : $953-963$.

[16] 丁新峰, 郝广, 董轫, 王宇坤, 高韶勃, 陈否, 何兴东, 赵念席, 高玉㭉.平茬处理对小叶锦鸡儿灌丛邻居植物群落空间格局的影响. 生态 学报, 2019, 39(11): 4011-4020.

[17] 马文明, 刘军, 周青平, 陈红, 刘超文. 高寒草地灌丛化对土壤团聚体稳定性及有机碳分布特征的影响. 土壤通报, 2019, 50 (5): $1108-1115$

[18] 王明明, 刘新平, 李玉霖, 车力木格, 罗永清, 孙珊珊, 魏静. 不同植被盖度沙质草地生长季土壤水分动态. 中国沙漠, 2019, 39( 5) : 54-61.

[19］罗梦娇, 艾宁, 刘长海, 刘广全, 强大宏, 李阳. 半干旱黄土区不同植被类型对土壤水分的影响. 四川农业大学学报, 2019, 37(2) : 177$184,177-184,191-191$.

[20] 于露, 周玉蓉, 赵亚楠, 郭天斗, 孙忠超, 王红梅. 荒漠草原土壤种子库对灌丛引人和降水梯度的响应特征. 草业学报, 2020, 29(4)： 41-50.

[21] 宋乃平, 杨明秀, 王否, 王兴, 肖绪培, 曲文杰. 荒漠草原区人工柠条林土壤水分周年动态变化. 生态学杂志, 2014, 33(10) : 2618-2624.

[22] Loik M E, Breshears D D, Lauenroth W K, Belnap J. A multi-scale perspective of water pulses in dryland ecosystems: Climatology and ecohydrology of the western USA. Oecologia, 2004, 141(2):269-281.

[23] 魏楠, 赵凌平, 谭世图, 赵芙蓉. 草地灌丛化研究进展. 生态科学, 2019, 38( 6) : 208-216.

[24] 班嘉蔚, 殷祚云, 张倩媚, 韦明思. 广东鹤山退化草坡从草本优势向灌木优势演变过程中的生态特征. 热带地理, 2008, 28(2): 129-133.

[25] 图雅, 刘艳书, 朱媛君, 杨晓晖, 张克斌. 锡林郭勒草原灌丛化对灌丛间地草本群落物种多样性和生物量的影响. 北京林业大学学报, $2019,41(10): 57-67$.

[26] Zavaleta E S, Kettley L S. Ecosystem change along a woody invasion chronosequence in a California grassland. Journal of Arid Environments, 2006, $66(2): 209-306$.

[27] Ónodi G, Kertész M, Lengyel A, Pándi I, Somay L, Szitár K, Kröel-Dulay G. The effects of woody plant encroachment and wildfire on plant species richness and composition: Temporal changes in a forest-steppe mosaic. Applied Vegetation Science, $2020,1-11$.

[28］王红梅, 王壁. 景观生态界面边界判定与动态模拟研究进展. 生态学报, 2017, 37( 17) : 5905-5914.

[29］王红梅, 王堮. 景观生态界面综合研究及展望. 草地学报, 2017, 25(1): 1-7.

[30］彭海英, 李小雁, 童绍玉. 内蒙古典型草原灌丛化对生物量和生物多样性的影响. 生态学报, 2013, 33(22): 7221-7229.

[31] 邬建国. 景观生态学一格局、过程、尺度与等级.第二版. 北京: 高等教育出版社, 2007.

[32] Rizvi A, Aziz S. Spatiotemporal seed bank flora of peristrophe paniculata community in a semi-arid desert of karachi, Pakistan. Pakistan Journal of Botany, 2015, 47(5): 1875-1878.

[33] 彭海英, 童绍玉, 李小雁. 内蒙古典型草原土壤及其水文过程对灌丛化的响应. 自然资源学报, 2017, 32(4) : 642-653.

[34] 赵亚楠. 宁夏东部荒漠草原灌丛引人过程中土壤水分、碳氮空间演变及水分阈值研究 [D]. 银川: 宁夏大学, 2019.

[35] 赵亚楠, 杜艳艳, 马彦平, 赵延兵, 周玉蓉, 王红梅. 宁夏东部荒漠草原灌丛引人过程中土壤有机碳变化及其空间格局预测. 应用生态学 报, 2019, 30(6):1927-1935.

[36] 李志强, 王明玖, 陈海军, 孙熙麟. 短花针茅荒漠草原土壤种子库对不同放牧强度的响应. 干旱区资源与环境, 2010, $24(6)$ : $184-188$.

[37] 李秋艳, 方海燕. 荒漠绿洲边缘区泡泡刺灌丛土壤种子库研究. 干旱区研究, 2008, 25(4): 502-506.

[38] 何芳兰, 郭春秀, 马俊梅, 吴吴, 金红喜. 民勤绿洲边缘梭梭林衰败过程中土壤种子库动态及其与地上植被的关系. 生态学报, 2018,38 (13) :4657-4667. 